\title{
OBRAZ STAREGO CZLOWIEKA W PRASIE. ANALIZA DYSKURSU W TEKSTACH O STAROŚCI W TYGODNIKU ,POLITYKA” W 2012 R.
}

\author{
Animage of Old Man in the Press. A Discourse Analysis about Agening \\ in "Polityka" (Weekly, 2012)
}

Keywords: discourse analysis, ageing, being old, press

Contact: Uniwersytet Wrocławski; maria.rudnicka@uwr.edu.pl

\section{Starość i rola ludzi starych}

Świat zachodni starzeje się. Liczebność ludzi starych (na potrzeby tego artykułu przyjmijmy, że to osoby po 60 . roku życia) w społeczeństwach zachodnich jest wyższa niż kiedykolwiek, a prognozuje się, że w 2030 r. w Polsce grupa ta będzie stanowić 29,8 \% społeczeństwa (na początku minionego wieku było niewiele ponad $3 \%$ ); podobnie - żyjemy ponad dwukrotnie dłużej, w lepszym zdrowiu niż pół wieku temu (na przełomie XIX i XX w. na ziemiach historycznie polskich ludzie żyli średnio 33 lata, dziś w Polsce to średnio 78 lat). To wynik rozwoju medycyny, industrializacji i poprawy warunków higienicznych.

Mimo tego pozycja społeczna osób starych nie jest wysoka. Wynika ona $\mathrm{z}$ ograniczeń wiążących się z tym okresem życia, powodowanych $\mathrm{m}$. in. zmianami inwolucyjnymi i zakończeniem pracy zawodowej (oznacza to zaprzestanie utrzymywania kontaktów z osobami decyzyjnymi oraz, w realiach polskich, znaczne obniżenie dochodów). To jednak nie jedyne przyczyny. Dziś funkcjonujemy w społeczeństwie prefiguratywnym, w którym to młodzi pomagają przedstawicielom najstarszych pokoleń radzić sobie w rzeczywistości, zatem starzy nie mogą być autorytetami, jak bywa to w społeczeństwach postfiguratywych (model wspólnoty), w której to osoby starsze są autorytetami przekazującymi młodym wiedzę o świecie (por. Mead 2000). Pozycja ludzi starych wiąże się także ze zmianą sposobu budowania wspólnot i z rozwojem technologii (Internet, nowe media, por. Bauman 2000) oraz zjeunizmem, czyli promowaniem ludzi młodych (to odmiana ageizmu, dyskryminacji ze względu na wiek). Przejawia się to $\mathrm{m}$. in. w lekceważącym traktowaniu ludzi starych 
czy traktowaniem ich jako obcych, nie należących do kultury.

Wszystko to sprawia, że nie mówi się o tej grupie społecznej. Obserwować to można w zachowaniach samych osób starych, ale tematu unika się także na poziomie języka (eufemizacja określeń związanych z wiekiem) i na poziomie dyskursów.

\section{Cel analizy i metodologia}

Celem niniejszej analizy jest zbadanie dyskursu o starości. Autorka wychodzi z założenia, że język kształtuje procesy i stosunki społeczne, zatem to uzasadnia niezwykłą rolę dyskursu w kreowaniu roli osób starych w społeczeństwie. Dyskurs to zdarzenie komunikacyjne służące do przekazywania idei i przekonań; zarówno tekst pisany, jak wypowiedź ustna (van Dijk 2001: 15). Analiza dyskursu to badanie interdyscyplinarne, pozwalające na zrekonstruowanie przekonań, opinii i ideologii autorów tekstów, tym samym - na odtworzenie sposobu postrzegania starości.

Badaniu zostały poddane różnorodne teksty prasowe podejmujące tematykę starości opublikowane w tygodniku „Polityka”, jednym z najbardziej opiniotwórczych tygodników w Polsce, w roku 2012 (ogłoszonym przez Parlament Europejski Rokiem Aktywności Ludzi Starszych i Solidarności Międzypokoleniowej).

Autorka sprawdziła, (1) jakie obrazy starości i starych ludzi jawią się w tekście, (2) jakie słownictwo stosowane jest do opisu. Ważne było też (3) określenie emocji związanych z tymi obrazami (pozytywne czy negatywne). Zadano następujące pytania:

1. Czy w analizowanym dyskursie przeważają obrazy pozytywnie czy negatywnie wartościujące starość?

2. Jak określa się ludzi starych $\mathrm{w}$ analizowanych artykułach (środki leksykalne, metafory, styl, środki retoryczne; odwołanie do stereotypów)?

3. Jakie emocje są nazywane i / lub opisywane bądź też wyrażane nie wprost w analizowanych artykułach? (por. Miller 2012).

Przeanalizowano 23 teksty o różnorodnej tematyce: kwestie ekonomiczne, reforma emerytalna, systemy emerytalne w innych krajach, pomysły opieki nad osobami starszymi itd.

\section{Wyniki analizy}

1. Czy w analizowanym dyskursie przeważają obrazy pozytywnie czy negatywnie wartościujące starość? 
Aby odnieść się do powyższego problemu badawczego, uporządkowano obrazy, jawiące się w związku ze starością. Jest ich kilka, wszystkie zostaną opisane.

\subsection{Samotność}

\section{1.a. Zamknięcie w domu, zakończenie relacji społecznych}

Ten okres życia to czas tracenia kontaktów: „Wokół (...) robi się pusto, ich relacje społeczne gasną" (Growiec 2012: 61). Partnerzy życiowi odchodzą. Utrata kontaktów to realna trudność dla mieszkańców domów opieki, którzy czekają „na kontakt z bliskimi, jest to właściwie (...) jedyna przyjemność" (Winnicka 2012: 67).

Czas w samotności nie jest łatwy: „Życie w pustym gnieździe często okazuje się trudne" (Barbaro 2012: 82); wiąże się z brakiem zajęcia: ,jeśli wstanę o dwunastej, siądę przed telewizorem i będę przed nim siedzieć, może być tak, że nikt ani nic się o mnie nie upomni” (Barbaro 2012: 83). Spędza się czas w domu, bo tylko tam jest dobrze: „Osoby starsze najchętniej pozostają we własnych mieszkaniach, tam czują się bezpiecznie” (Kornatowski, Musiałowicz 2012: 106); bywa to przyjemne: „Czasem, kiedy jest najładniej z kwiatowej perspektywy (...), wynosi taborecik do ogródka pod balkonem i patrzy (...)" (Gietka 2012: 153). Trudno nie zauważyć, że starszej osobie zostaje często już tylko obserwowanie rzeczywistości, wiąże się to więc z nudą w tym wieku.

\section{1.b. Samotność w wyniku choroby}

Schorzenia stawiają poza nawiasem społeczeństwa. To może być choroba Alzheimera, powodująca, że się „dziecinnieje, ma coraz większą demencję, zapomina, pyta piąty raz (...) o to samo" (Winnicka 2012: 68). Utrudniają kontakt z rzeczywistością i możliwość pracy: „ręce ograniczył Parkinson. Podlała dwa, trzy kwiatki i musiała odpocząć. Mąż już od dawna nie ma z kwiatów pociechy, gdyż miażdżyca odebrała mu poczucie rzeczywistości” (Gietka 2012: 152).

\section{1.c. Poczucie bycia nieważnym}

Rzadko kiedy starość ma sens „Z początkiem lipca, kiedy na Woli zawiązuje się balkonowa komisja, pani Krystyna, lat 72, przestaje spacerować bez celu (Gietka 2012: 152). W domyśle czytelnik jest informowany, że starszy człowiek nie robi nic ważnego; z drugiego cytatu wynika, że przestaje się liczyć: „Oprócz komisji balkonowej nikt nie zatrzymuje się pod balkonem na Służewie (...). Minęły lata. Pan Wacław już przestał 
mieć znaczenie w innym niż kwiatowy kontekście" (Gietka 2012: 153).

\subsection{Starość jest nudna}

To jest powiedziane wprost: „Oprócz corocznego balkonowego konkursu, w życiu starszego pana niewiele się dzieje" (Gietka 2012: 152). Znaczenie tego wydarzenia umniejsza fakt, że dotyczy balkonu - jak wynika z tekstu to coś, co nie jest do końca prawdziwe, rodzaj złudzenia: „Ludziom zamkniętym w blokoprzestrzeni daje pozór skrawka ziemi”. Tytuł innego artykułu: Fajeczka, gołabeczek, taweczka, ogródeczek...1 (J. Dziadul) to opis stylu życia starych górników: palą fajki, hodują gołębie, siedzą na ławce w ogródku. Efektem nudy i braku kontaktów są przestępstwa: „We Francji wzbiera fala przestępczości wśród staruszków" (Mizierski 2012: 110).

Tych, którzy mają zajęcie, nie jest wielu: „Nieliczni seniorzy dają przykład, że sędziwy wiek nie musi oznaczać (...) braku aktywności” (Bunda, Walewski 2012: 25).

\subsection{Stary człowiek jest wykluczony z (nowych) mediów}

Utrudnione jest kontaktowanie się ze światem zewnętrznym za pomocą Internetu: „linią graniczną, dzielącą dziś ludzi na tych, którzy za nowymi technologiami nadążają, i tych, którzy już nie są w stanie ich opanować, jest wiek 45 lat" (Solska 2012: 36). Nie tylko - ograniczona jest także obecność osób w późnej dorosłości w mediach: „Rok temu 52letnia wściekła dziennikarka stacji BBC (...) poinformowała media, że przełożony poprosił ją o zlikwidowanie zmarszczek botoksem. Gdy odmówiła, zdjął ją z wizji” (Winnicka 2012: 69).

\subsection{Starość jest niechciana w społeczeństwie}

Trudno oprzeć się wrażeniu, że władze nie podejmują odpowiednich działań wobec zmieniającej się demografii społecznej: „Reforma, wydłużająca wiek emerytalny, jest sierotą. Właściwie nikt jej nie chce" (Solska 2012: 35). Zastosowano tu porównanie reforma jest samotna, opuszczona, to rzuca mocny cień także na starość, wymuszającą tę reformę.

Społeczeństwo uznaje, że ten okres życia wiąże się z komplikacjami i niszczy młodych w wielu wymiarach „Opieka nad starymi (..) dewastuje (...) finansowo i fizycznie, niekiedy - także moralnie” (Bunda, Walewski 2012: 26). To głównie młodzi

\footnotetext{
${ }^{1}$ To refren popularnej piosenki biesiadnej o starości górnika pt. Starzyk autorstwa Z. Pyzika.
} 
muszą konfrontować się ze starością, ale ponieważ są z nią sami, niejednokrotnie trudności przerastają ich możliwości psychiczne czy fizyczne: „Nawet najwięksi herosi po kilku latach padają ze zmęczenia”. W niniejszym zdaniu warto zwrócić uwagę na określenia: padać ze zmęczenia oraz po kilku latach, uświadamiające czytelnikowi przewlekłość sytuacji. Nikt nie podejmuje odpowiedzialności za wsparcie opiekunów: „Nie ma w Polsce systemu, który zapewniałby wytchnienie osobom obarczonym opieką nad starszymi krewnymi przez okrągły rok 24 godziny na dobę" (Bunda, Walewski 2012: 26); opieka ta jest odpowiedzialnością familii. Na decyzje samorządów (to one są odpowiedzialne m. in. za opiekę społeczną) wpływa ich opłacalność: „Większość wyborców preferuje więc nowe chodniki, a nie awangardowe rozwiązania socjalne" (Bunda, Walewski 2012: 26). Co więcej, ,podsystem medyczny też jakby się uparł, żeby ignorować istnienie seniorów" (Bunda, Walewski 2012: 25) w podobnym tonie utrzymane jest zdanie: „Dyrektorzy szpitali bronią się przed oddziałami geriatrycznymu" (Bunda, Walewski 2012: 25), bo są one nieopłacalne; zatem starość w ogóle nie opłaca się, należy ją ignorować albo chronić się przed nią.

Ostatecznie wzrost populacji osób starszych powoduje jej akceptację „Wobec starości (...) staliśmy się ostatnio bardziej wyrozumiali - jakby godząc się z tym, że coraz więcej ludzi może (...) dożyć sędziwego wieku" (Bunda, Walewski 2012: 26) zatem starość to coś niechcianego, co trzeba zaakceptować, ale ostatecznie, niechętnie.

\subsection{Starzy ludzie są poza rynkiem}

Nie mają dostępu do pewnych usług: ze względu na wiek „Za chwilę miał przyjechać kurier $\mathrm{z}$ nowym aparatem i umową do podpisania. «Tylko jeszcze poproszę parę pańskich danych (...) Najpierw PESEL... » i w tym momencie transakcja została przerwana” (Adamczewski 2012: 8) albo z powodu niskich emerytur: „Dla emeryta, który nie ma za co wykupić lekarstw" (Mizierski 2012: 110).

\subsection{Starość z perspektywy starca}

W kilku artykułach można przeczytać o doświadczaniu starości przez samych seniorów. Często muszą oni konfrontować się z cudzą śmiercią: „Co roku od nowa pani Krystyna odwiedza swoich balkonowych faworytów. Czasem słyszy w domofonie: przepraszam, mąż / żona umarła" (Gietka 2012: 152); ten czas to też kończenie niektórych własnych aktywności: „W ubiegłym balkonowym sezonie postanowiła ostatecznie rozstać się z kwiatami. Zabrał je listonosz" (Gietka 2012: 152) - warto zauważyć, że to zadanie to wykonał pracownik instytucji zajmuącej się dostarczaniem korespondencji, w domyśle 
dlatego, że nie ma nikogo innego, kto mógłby to zrobić.

W tekście Miks DJ Wiki (Smyrska 2012: 103) wypowiadają się osoby starsze na temat miłości i seksu („Mężczyźni z naszego otoczenia używają viagry.”; „Po sześćdziesiątce można się zakochać na nowo.”); nie obcy im jest problem higieny osobistej, dotykający niektórych przedstawicieli generacji: „Istotne w naszym przemijaniu jest dbanie o siebie, i nie mówię tylko o sferze psychicznej”" (Smyrska 2012: 104); „Niektórzy myślą, że jak spodnie są niedzielne, to już nie trzeba ich prać!”). O akceptacji wieku świadczy złożenie „nasze przemijanie”, które pokazuje utożsamianie siebie z procesem, on jest „nasz” (identyfikacja).

2. Jak określa się ludzi starych $\mathrm{w}$ analizowanych artykułach (środki leksykalne, metafory, styl, środki retoryczne, czy następuje odwołanie do stereotypów)?

Trudno wypisać wszystkie środki leksykalne, ponieważ jest ich wiele. Warto wymienić:

a. rzeczowniki: senior, aktor emeryt, dziadek, babcia, nestor rodu (Kyzioł 2012: 127), stary (Bunda 2012: 27), staruszek (Bunda, Walewski 2012: passim); emeryt (Stasiak 2012: 49). Sam wiek opisuje się za pomocą leksemu starość. Rzeczownikowe określenia osoby starszej są w większości neutralne albo negatywne; rzadko to rzeczowniki nacechowane pozytywnie (m.in. babcia, dziadek). W przypadku neutralnych tylko z kontekstu można odczytać nacechowanie emocjonalne (np. staruszek $\mathrm{w}$ tekscie Bundy i Walewskiego ma wydźwięk ironiczny).

b. przymiotniki: dojrzate (aktorki dojrzałe; Kyzioł 2012: 127), ,zreformowane (emerytki)" - tu określenie odnosi się do kobiet otrzymujących emeryturę po reformie i wynika z ekonomizacji języka (Solska 2012: 37), starszy pracownik (Solska 2012: 36). Uwagę zwraca użyty w kontekście starości przymiotnik opłacalny („Gdyby leczenie starych ludzi było opłacalne"; Bunda, Walewski 2012: 26). O grupie seniorów mówi się też Odwróceni (Szyperska 2012: 50); to gra słowna - określenie grupy, która zdecydowała się na odwróconą hipotekę; nie jest to określenie w pełni neutralne - odwrócone jest bowiem to, co nie ma naturalnego porządku.

c. czasowniki, konstrukcje czasownikowe: tryb warunkowy w zdaniu „Gdyby leczenie starych ludzi było opłacalne" uświadamia czytelnikowi nierealność tego założenia 
(Bunda, Walewski 2012: 26). Mówi się też, że wokót nich robi się pusto, ich relacje społeczne gasna - frazeologizm: robić się pusto, sformułowanie relacje społeczne gasna to ostateczne określenia, oznaczające nieuchronny koniec czegoś, starość zatem wiąże się z końcem.

d. konstrukcje gramatyczne, zwroty, frazemy: np. 50+, jesień życia, koszmarne dożywocie (Bunda 2012: 28), wiek emerytalny (Bunda, Walewski 2012: 24); siwa przestępczość (Mizierski 2012: 110). O ile 50+ to bardzo neutralna, wiążąca się z ekonomią języka konstrukcja a jesień życia jest bardzo pozytywną metaforą starości, o tyle nikt nie chce być skazany na koszmarne dożywocie ani mieć do czynienia z siwa przestępczościa.

e. środki retoryczne: W tytule Starość - problem młodych starość jest równoznaczna z problemem; dwa zdania później określona jako wręcz narastajacy problem, zatem zwiększający się, coraz trudniejszy. W innym zdaniu w tym tekście („Nawet najwięksi herosi po kilku latach padają ze zmęczenia") pokazano, że mitologiczni bohaterowie nie poradziliby sobie ze starością, a synowie i córki herosami nie są; opieka nad starymi rodzicami to coś ponad siły zwykłego człowieka. Armia staruszków wywołuje rozbawienie w oczach czytelnika: $\mathrm{z}$ jednej strony przywołuje obraz grupy silnych, zdyscyplinowanych ludzi, drugi jej element to określenie ludzi starych, którym brakuje siły i są schorowani (oksymoron). Podobnie komiczny efekt wywołuje zdanie: „tak, żeby senior nie skakał po taboretach" (Bunda, Walewski 2012: 25). Z kolei skojarzenie z rzeczą niechcianą, kukułczym jajem, wywołuje określenie: podrzucać do szpitala (Bunda, Walewski 2012: 26). Zastosowano jeszcze jedno porównanie - w artykule Starość: problem mlodych porównano ten okres życia do niezdarności: „więc nie wypada piętnować niezdarności u innych” (Bunda, Walewski 2012: 25).

Pojawiają się zaprzeczenia stereotypów, potwierdzające ich istnienie: DJ Wika nie jest typowa babcią; nowa starość - aktywna, niebierna, w domyśle: lepsza. Ta stara starość to „gra w szachy, prace w ogródku, spacery czy pogawędki z rówieśnikami” (Mizierski 2012: 110).

3. Jakie emocje są nazywane i / lub opisywane bądź też wyrażane nie wprost $\mathrm{w}$ analizowanych artykułach?

W większości tekstów uderza smutek wiążący się z wiekiem i wynikającymi z niego problemami, jedynym wyjątkiem jest tekst Miks $D J$ Wiki, w którym starość jest 
obrazowana może nie entuzjastycznie, ale z szacunkiem i pozytywnie (,dojrzałość ma swój urok").

Choć występują rzeczowniki i przymiotniki zarówno neutralne, jak i negatywne, trzeba zauważyć rzadkie użycie tych pozytywnych; podobnie dzieje się w obszarze czasowników. Starość jest raczej niechciana, odrzucana przez młodych, jak i przez starych, nudna i nieciekawa, bycie starym wiąże się z kończeniem aktywności i przywiązaniem do określonego miejsca. W niektórych przypadkach zauważa się dystansowanie się autorów artykułów wobec tego okresu życia; jeden z autorów (Piotr Adamczewski, autor-senior) mówi by „skasować starość jako taką” (Adamczewski 2012: 8), zatem wyrażona jest wielka do niej niechęć.

\section{Podsumowanie}

Obraz starości zrekonstruowany na podstawie analizy artykułów opublikowanych w tygodniku „Polityka” w 2012 roku (zarówno na poziomie leksykalnym, gramatycznym, jak i na poziomie obrazów) jest depresyjny i pełen niechęci do tego okresu życia, budzi smutek. Słownictwo jest neutralne bądź negatywne, sporadycznie pojawiają się określenia pozytywne i nieliczne pozytywne obrazy, dominuje negatywny wachlarz emocji i obrazowań. Świadczy to strachu przed tym okresem życia i brakiem akceptacji dla wieku, dla demografii i powinno wywołać niepokój socjologów i osób zajmujących się polityką społeczną, ponieważ, jak powiedziano na początku, język kształtuje procesy i stosunki społeczne - taki obraz starości w tak ważnym czasopiśmie może utrzymywać negatywny obraz wieku i niekorzystnie wpływać na jakość życia osób w późnej dorosłości, zatem na niemal 30 \% członków społeczeństwa.

\section{Summary}

The reconstructed image (based on analysis of the weekly Polityka) of old age is depressing and full of resentment. The vocabulary and pictures of being old is neutral or negative, occasional positive. This demonstrates the fear of lack and acceptance of this period of life. It should alarm sociologists and social policy workers because, as was said at the beginning, language shapes processes and social relations. This kind of picture in such an important journal can maintain negative image of age and affects the quality of life of people in late adulthood (almost $30 \%$ of society). 


\section{Literatura}

Adamcewski, P. Prezent urodzinowy. Polityka. 30.05.2012 (22/2860), s. 8.

Barbaro, de B. Kiedy będziesz starą kobietą. Polityka. Ja My Oni. Poradnik Psychlogiczny. 22.02.2012 (2/2), s. 81-84.

Bauman, Z. Globalizacja i co z tego dla ludzi wynika. Tłum. Klekot, E. Warszawa: PIW, 2000.

Bunda, M. Marudzenie o rodzeniu. Polityka. 17.10.2012 (42/2879), s. 26-30.

Bunda, M., Walewski, P. Starość: problem młodych. Polityka. 29.08.2012 (35/2872), s. 24-27.

Dijk van, T. Badania nad dyskursem. In: Dijk van, T. (ed.) Dyskurs jako struktura i proces. Tłum. Grochowski, G. Warszawa: PWN, 2001.

Gietka, E. Powiązanie z pelargonią. Polityka. 25.04 .2012 (17/2865), s. 152-153.

Growiec, K. Blisko z bliźnim. Polityka. Ja My Oni. Poradnik Psychologiczny. 22.02.2012 (2/2), s. 61-63.

Kornatowski, M. A., Musiałowicz, A. A może opieka na telefon. Polityka. 19.09.2012 (38/2875), s. 106.

Kyziol, A. Aktor się zaczyna, kiedy się kończy. Polityka. 19.12.2012 (51/2888), s. 126 129.

Mead, M. Kultura i tożsamość: studium dystansu międzypokoleniowego. Tłum. Hołówka, J. Warszawa: 2000.

Miller, D. Ze Wschodu na Zachód, czyli wielopłaszczyznowa lingwistyczna analiza dyskursu w pigułce. In: Piekot, T., Poprawa, M. (eds.) Analiza dyskursu. Centrum - peryferie. Wrocław: Wydawnictwo Uniwersytetu Wrocławskiego, 2012, s. $155-172$.

Mizierski, S. Starość musi się wyszumieć. Polityka. 16.05.2012 (20/2858), s. 110.

Smyrska, M. Miks DJ Wiki. Polityka. 04.07.2012 (27/2865), s. 100-105.

Solska, J. Trzy razy nie. Polityka. 25.01.2012 (4/2843), s. 35-37.

Stasiak, P. Wylogować się z systemu. Polityka. 23.05.2012 (21/2859), s. 48-50.

Szyperska, U. Odwróceni. Polityka. 28.11.2012 (48/2885), s. 50-51.

Winnicka, E. Chorzy na młodość. Polityka. Ja My Oni. Poradnik Psychologiczny. 22.02.2012 (2/2), s. 67-69. 